\title{
計画転作に和ける農地賃貸借の実態と 小作料の形成要因
}

宮崎猛

\section{1.はじめに}

最近，「地域内農地利用の集団的コントロール」の 必要性が強く主張され，その実態もいくつか指摘され ている ${ }^{1)}$. 今仮りにこのような土地利用関係を集団的 土地利用と呼称するならば，集団的土地利用の具備す

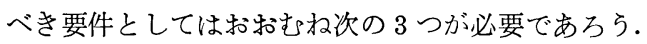

第1の条件は集落の自治組織（農家組合, 農事実行 組合）や農協等の公的機関が農地貨貸借や土地利用に ついて最低限次の 3 つの管理・調整機能を遂行してい ることである.

i）「借地仲介機能」と言われるものであり，土地利 用権の調達及び分配に関する管理・調整機能.

ii）土地所有権あるいは利用権の「集団的保障機能」 と言われるものであり，農地の貸付農家と借入農家と の間に括ける権利関係及び土地利用期間や小作料など に関する管理・調整機能.

iii）「合理的な土地利用増進機能2)」と言われるもの であり，借入農家・耕作者関する土地利用上の指導 や調整機能または借入地の経営管理機能

第 2 の条件は地域的に限定された地区内に借地農家 の連合組織であるソフトな耕作者集団が存在するこ と.これらは通常, 部門協業経営組織または共同作業 型集団裁培組織のタイプに属する生産組織である。 た多くの場合は第 1 の条件の属地的公的機関と第 2 の 条件の機能的生産組織が併存しているわけであるが, 中には例外的飞属地的公的機関が借入地の経営管理機 能を遂行している場合もある.

第 3 の条件は対象作物のために利用する農地が立地 上同一地区内に集中していること，すなわち対象作目 についてハードな生産団地が存在することである.

ところで昭和 53 年度から実施されている水田利用再 編対策に执いては，「地域ぐるみ計画的転作」（以下 計画転作と呼称する。）がある。これについては転作 奨励金の中に計画加算金を上積みして優遇している. 計画転作の事例には計画転作の条件を大規模農家の単 なる個別的対応によって消化したものも少なくない
が，中には計画転作への取り組みの中で集団的土地利 用の形態を生み出してきた優れた事例も存在する。 そ の場合は必ず農地賃貸借によって計画転作が成立して いる.

集団的土地利用の条件を備えた計画転作には, 第 1 に水田を畑地として利用する転作行為であること．第 2 亿強行な行政の誘導施策によって推進されたこと. などの理由から従来の協業経営組織や農用地利用増進 事業拉よび農協経営委託事業などに括汀る農地賃貸借 の仲介機関とは異なる特殊性が存在する.

本稿では計画転作およびその取り組みの中で形成さ れた農地賃貸借を考察対象とし, 次の 2 つの課題につ いて検討する. 第 1 は計画転作の類型化を試み，従来 の協業経営組織や農地賃貸借に関する仲介機関とは異 なる計画転作に㧍ける組織，機関の特殊性を明らかに する. 第 2 は計画転作における小作料の経営経済的形 成要因について分析する.

上記課題の分析のために「止田利用再編対策の実施 に伴う農業動向調查結果」（昭和53年度, 近畿農政局 生産流通部, 調查地区 : 兵庫県竜野市揖保中, 京都府 加悦町後野) 括よび「地域農業経営改善調查結果」(昭 和54年度, 近畿農政局企画調整室, 調査地区 : 奈良県 桜井市織田，滋賀県高月町柏原）を利用した。

\section{2. 計画転作の特殊性とその類型}

\section{(1) 計画転作の特殊性}

計画転作に括汀る生産組織とくに部門協業経営組織 には従来の協業経営組織とは異なる特徵がある。それ は第 1 亿転作以前にあった機械共同利用組織や集団裁 培組織が発展して部門協業経営組織が成立している. 第 2 亿機能的生産組織の存在しない地区では地縁的自 治組織である農家組合や農協が転作の経営管理主体と なっている. 第 3 亿計画転作に伴ら部門協業経営は個 別農家の農業経営をあくまで補完する存在意義しかも たない，第 4 亿生産組織構成農家以外からも農地を貨 借することにより経営地が調達されている。などであ る. 
また前述した農地貨貸借に関する 3 つの管理・調整 機能を遂行する集落の自治組織や農協には，従来の農 用地利用増進事業や農協経営受委託事業に拈ける農地 貢貸借に関する仲介機関にはみられなかった土地所有 権あるいは土地利用権に対する強い規制力が存在す る. 貸付農家の土地所有権については i ) 計画転作対 象地区の指定, ii ) 転作作物の強制的作付けに上っ て, 自由な使用・収益・処分の権利を一時的に制約で きる. 借入農家の土地利用権についてはｉ） 1 年間の 短期契約であることから借入農家に費用償還請求権, 契約の継続権は認められない，ii）転作奨励金等が借 入農家の小作料支払能力を向上させていることから小 作料減免権は存在しない. iii) 転作行為であること, 生産組織（集団）が経営管理主体となっていることか ら借入農家の経営主宰権は制限される。などの点で公 的機関の規制力が働いている.

\section{(2) 計画転作の類型}

集団的土地利用とは水系や農道を単位にまとまった 地区内の生産団地について，地縁的公的機関による農 地賃貸借・土地利用に関する管理・調整機能を仲立ち として，機能的生産組織が特定作物について集団裁培 または部門協業経営を行うことである. 集団的土地利 用にとって農地賃貸借は不可欠の必要条件であるが， 計画転作には必要でない場合がある，有志農家が自作 地内で計画転作を消化した場合がその事例である．他 方農地貨貸借によって成立した計画転作は集団的土地 利用であると判断できよう．本稿では前述した集団的 土地利用の 3 つの要件を具備した計画転作を考察対象 としており，その限りで計画転作を類型化する. 計画 転作についてハードな生産団地形成のための土地利用 権調達方法, ソフトな生産組織への参加者（利用権の 分配農家) の内容, 生産組織の形態とい5 3 つの要因 から分類すると次の 4 類型に区分できる

\section{A）集落ぐるみ型}

集落内農地のうち転作可能な水田全部が長期的には 計画転作の対象となり, 集落内の農地をいくつかのブ ロックに区分し，ある年の計画転作対象地区を 1 ブロ ックに限定した上で毎年対象地区を変光，10年前後の 期間でブロックローテーションを完了させる方式であ る. 計画転作の団地形成の対象農地が集落全体の農家 の所有地であり，集落内全農家が計画転作に関与する といら意味で集落ぐるみ型と呼ぶ.

この類型の土地利用方式は従来から集団的田烟輪換 に招いて採用されてきたものと同一であり，連作障害
の発生を回避するための対策である点も集団的田畑輪 換と同様である. しかし計画転作が従来の集団的田畑 輪換と異なる点は経営管理主体が多くは機能的生産組 織であり, 農地賃貸借に関する管理・調整機関が土地 所有権や土地利用権に対して強い規制力をもっている ことである. その場合公的機関による土地所有権，土 地利用権への規制が集落内の大半の農地に及び，かつ 長期間の土地利用計画が存在するといら点でこの類型 の土地利用方式は計画性が高い.またこの類型の土地 利用方式の利点は計画転作に集落内全農家が関与する ことにより，地域農業組織化に大きく貢献しているこ とである. その場合集落内農地の土地利用・農地賃貸 借に関する管理・調整機関は通常集落の自治機関（農 事実行組合, 農家組合) が担当している.

この類型の場合, 転作物耕作者及び彼らが参加して (る機能的生産組織の種類の差異に応じて, a) 中核 農家・部門協業経営組織型とb）兼業農家ぐるみ・集 団裁培組織型にさらに細分できる。a）においては耕 作者は中核農家に限定されて括り, 中核農家の組織す る機能的集団は部門協業経営体である. それゆ兄生産 物の所有権は生産組織にあり, その参加者二中核農家 は労賃と収益分配分を受け取る. 経営の危険負担は協 業経営体が行うｂ）に打いてては耕作者は兼業農家を 含めた幅広い農家階層であり, 集団裁培組織は通常農 事実行組合等の下部機関として構成されている. この 場合転作物の経営形態は家族経営であり, 土地利用権 の移動調整や集団裁培・共同作業を推進する集落組織 はあくまで個別農家の農業経営を補完するものにすぎ ない.この類型では土地利用権は次のように移動する.

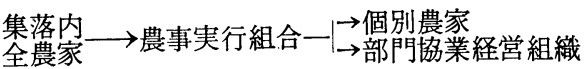

B) 生産組織型

計画転作の対象となる水田は農地賃貸借を通じて団 地化されるが，この類型では転作物の耕作を中核農家 集団二機能的生産組織が担当するわけである.この類 型の場合集落内農地をブロックローテーションすると いら生産の長期計画性の無い点で A - a ) 類型と区別 される，その限りで従来水稲作において農協や生産組 合を仲介機関として発生してきた土地利用権の移動形 態と類似しているわけである.この類型の場合，中核 農家の参加する生産組織の種類の違いに応じて, 部門 協業経営組織型と集団裁培組織型に細分できる.
a）部門協業経営組織型
転作物の経営形態, 生産物の所有権, 中核農家の取 
分などは $\mathrm{A}$ - a ）類型と同様であるが, この場 $\mathrm{A}$ - a ) と違う点は土地利用権の移動を管理・調整する機関が 農協や生産組織自体である場合が少なくないことであ る. それゆえこの類型では土地利用権は次のように移 動する.

\section{集落内の $\longrightarrow$ 豊事专行行組合 $\longrightarrow$ 部門協業経営組織}

\section{b）集団裁培組織型}

転作物の経営形態, 生産物の所有権などは $\mathrm{A}-\mathrm{b}$ ) 類型と同様であり，土地利用権の移動を仲介する公的 機関については B-a）と同様のことが妥当する.こ の類型の特徵は本来中核農家集団としてのまとまりが 弱いことから, 計画転作の対象となる水田は中核農家 集団の自作地を基礎としている点である. この類型で は土地利用権は次のように移動する.

$$
\text { 組織参加 } \longrightarrow \text { 農事褰協等 }
$$

計画転作の類型としてはこれだけでは不十分であろ ら, しかし前述したよらに集団的土地利用の 3 つの要 件を具備した計画転作に限定するならば上記 4 類型で ほぼ網羅できると思われる，ところで調査地区に拈け る計画転作について見ると，織田・大西地区は Aa ) 類型, 柏原地区は $\mathrm{A}-\mathrm{b}$ ) 類型, 揖保中地区は $\mathrm{B}$ - a ) 類型, 後野地区は B-b ) 類型に所属している.

\section{3. 計画転作における農地賃貸借と小作料 の実態}

\section{（1) 計画転作における農地賃貸借の実態}

計画転作に括ける借入農家の実態を表 1 に示した。 計画転作に拊斿る転作実施者は地区内でも経営面積規 模の大きな農家が多い。これに対して計画転作対象地 の所有者ではあるが転作には参加していない農家は所 有面積の零細な離農者やII兼農家が多い，ブロック口 ーテーション方式は全農家が貸付農家となり，転作希 望者はすべて借入農家となりらるシステムである。 しかし表一1の大西，柏原の事例では転作実施農家の 占める割合は大規模農家の方が高いことから，計画転 作に扮いては零細農家の大部分は転作物耕作に参加し ない土地用役供給者の性格が強いものと判断できる. それゆ方計画転作に括㚈る農地賃貸借は零細な II兼農 家から農業に意欲的な大規模農家への農地移動を促進 し，後者の規模拡大に貢献している.この原因として は裁培技術, 農業機械, 農業従事可能労働力などの違 いから，一方では飯米確保目的で水稲作を継続してき
表 1 計画転作の担い手

\begin{tabular}{|c|c|c|c|c|c|c|}
\hline \multirow{2}{*}{\multicolumn{2}{|c|}{ 経営面皘区分 }} & \multirow{2}{*}{ 揖保中 } & \multicolumn{2}{|c|}{ 織 田 } & \multirow{2}{*}{ 後野 } & \multirow{2}{*}{ 柏 原 } \\
\hline & & & 大 西 & 箬中中 & & \\
\hline \multirow{7}{*}{$\begin{array}{l}\text { 集 } \\
\text { 落 }\end{array}$} & $\sim 50$ a & 20 & 42 & 31 & 57 & 20 \\
\hline & $50 \sim 70$ & 10 & 10 & 6 & 10 & 14 \\
\hline & $70 \sim 100$ & 5 & 10 & 2 & 4 & 15 \\
\hline & $100 \sim 150$ & 3 & 4 & & 6 & 10 \\
\hline & $150 \sim 200$ & & & & 3 & 3 \\
\hline & $200 \sim 300$ & 2 & & & 3 & 2 \\
\hline & 小 計 & 40 & 66 & 39 & 83 & 64 \\
\hline \multirow{7}{*}{$\begin{array}{l}\text { 転 } \\
\text { 作 } \\
\text { 実 } \\
\text { 施 } \\
\text { 家 } \\
\text { 家 }\end{array}$} & $\sim 50$ a & 7 & 5 & & 4 & 16 \\
\hline & $50 \sim 70$ & 2 & 6 & & 2 & 4 \\
\hline & $70 \sim 100$ & & 9 & & 1 & 10 \\
\hline & $100 \sim 150$ & & 2 & & 3 & 8 \\
\hline & $150 \sim 200$ & & & & 2 & 3 \\
\hline & $200 \sim 300$ & 1 & & & 2 & 1 \\
\hline & 小 計 & 10 & 22 & 農 協 & 14 & 42 \\
\hline
\end{tabular}

注 (1) 集落内農家は昭和50年センサス結果より, 転作実施農 家は昭和 $53 ， 54$ 年の実態調査より.

(2) 単位: 戸

たII兼農家は技術革新の必要な転作物経営には消極的 であること．他方農業経営に意欲的な大規模農家は転 作物裁培について耕作能力の寡占的供給者であること が考えられる.

ところで計画転作における農地賃貸借には他の農地 貨貸借とは異なる特徵がある. 実態調査の結果（表 2）を見ると次の 3 つの特徵が挙げられる. 第 1 に水 田利用再編対策に方向づけられた 1 年限りの賃貸借で あり, 固場整備事業施工による仮換地のために賃貸借 と同様に短期間の土地利用調整の性格が強い：それゆ 兄第 2 亿農地法上ヤミ小作の形態で賃貸借が行われて いるが，実質的契約期間が長期化している通常のヤミ 小作とは違い，計画転作のヤミ小作の契約期間は実質 的にも 1 年である. 第 3 亿計画転作のための貨貸借に は又小作である場合が少なくない，水稲作目的の農地 賃貸借が成立している土地が計画転作の対象地とな り，その耕作者が転作物裁培を希望しない場合，土地 所有者之賃借人 (水稲作農家) 及び計画転作実施者の 3 者の間で又小作が行われる．その場合土地所有者と 賃借人 (水稲作農家) との間の農地貢貸借には, 農用 地利用増進事業による賃貸借や農地改革残存小作地, ヤミ小作など農地貨貸借の全類型が含まれている. 計 画転作に拈けるヤミ小作が又小作として行われている 場合, 計画転作の小作料は転作実施者から僓借人（水 稲作農家）飞支払われ，賃借人から土地所有者への小 作料支払いは当初の契約小作料で行われる. 計画転作 の小作料は転作奖励金をべースに計算されて括り，計 
表 2 調查農家における農地梖貸借の実態（昭和 54 年 8 月現在）

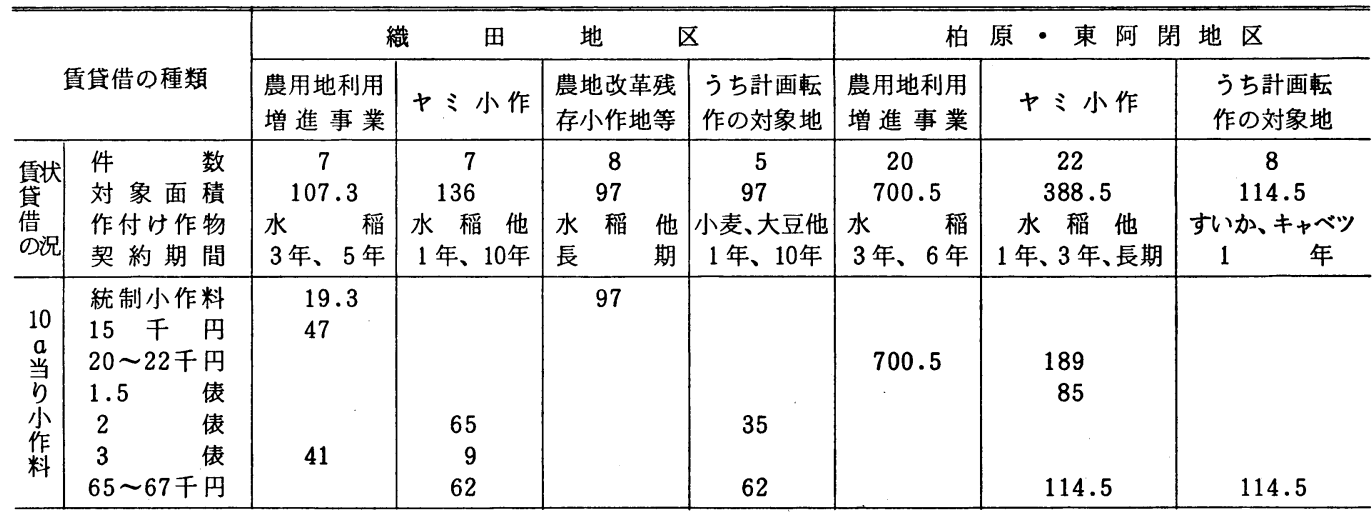

注 (1) 単位: $\mathrm{a}$, 件

（2）計画転作の対象地は貸付地のみ示した.

画転作の小作料は水稲作の小作料より高い水準にある

（表 3）。それゆえ又小作の場合でも賃借人は $4 \sim 6$ 万円 $/ 10 \mathrm{a}$ の差額報酬を得ることになる.

ところで個別経営の面積規模拡大を達成する方途で ある農地賃貸借について借入農家の利用権の安定性と いら観点から次の 2 つの土地利用権の管理・調整制度 に区分できるであろら，第1は又小作も含めた計画転 作における農地賃貸借である、計画転作における農地 賃貸借については農事実行組合が利用権移動の管理・ 調整を行う場合が多く，いわゆる集落の「土地資源管 理機能 $\left.{ }^{5}\right\lrcorner$ が発揮されている場合が多い. 水田利用再 編対策や集団的田畑輪換を目的とした集団的土地利用 における農地賃貸借は極めて短期間(通常 1 年)の利用 権移動でしかなく，それゆえこれによって達成される 個別農家の経営規模拡大は非常に不安定な状態であ る. その不安定な借入農家の土地利用権を補完し, 個 別農家の長期的規模拡大に結びつける可能性を与える 仲介機関が農事実行組合である.この場合集落の「土 地資源管理機能」の発揮しだいで，個別農家の経営規 模払大に農地賃貸借が結びつくか，単なる短期間の土 地利用調整に終るか大きく影響される．計画転作に括 ける農地賃貸借は極めて短期間の利用権移動である.

第 2 はおもに水稲作における農地貨貸借を対象とし た農用地利用増進事業や農協の経営受託事業などの利 用権仲介制度である. 土地利用権の管理・調整は市町 村あるいは農協が担当し, 契約期間も $3 \sim 6$ 年と利用 権も比較的安定性をもつ. またこの場合賃貸契約が更 新されて実質的な利用権移動は比較的長期間となる事 例が多い.この点では個別経営の規模拡大に直結する 制度である. しかし両事業の場合市町村や農協が完全
な「土地資源管理機能」をもっていることは少なく， これら事業は単なる土地利用権の仲介・あっせん制度 として機能している場合が多い.

計画転作における農地賃貸借を対象とした公的機関 による利用権の管理・調整制度は, 所有権と利用権に 対する強い規制力を基礎に土地利用の計画性, 地域農 業の組織化に結びついている点に特徵がある. その場 合個々の賃貸契約期間は短期間で非常に不安定である が, 長期土地利用計画と公的機関, 生産組織の存在が 意欲的農家の長期的規模扗大に貢献している.

\section{(2) 計画転作における小作料の実態}

調查地区について計画転作に和ける小作料の決定基 準に転作奖励金が考慮されているか否かについて見る と，転作奨励金を基礎に小作料を決定している地区が 織田, 後野, 柏原の 3 つである. 揖保中地区では10 a 当り小作料が 9 千円と転作奨励金とは無関係に決定さ

表 3 耕作者からみた計画転作における基準小作 料の内訳 (10 a 当り)

\begin{tabular}{|c|c|c|c|c|}
\hline & 項 & 織 田 & 後 野 & 柏 原 \\
\hline \multirow{5}{*}{$\begin{array}{l}\text { 小 } \\
\text { 作 } \\
\text { 料 } \\
\text { の } \\
\text { 内 } \\
\text { 訳 }\end{array}$} & 転作奚励 金 & 37 & 37 & 45 \\
\hline & 特定作物加算金 & $*$ & $* *$ & $* *$ \\
\hline & 計 画 加 算 金 & $*$ & 18 & 10 \\
\hline & 互 助 金 他 & 30 & 15 & 10 \\
\hline & 計 & 67 & 70 & 65 \\
\hline \multicolumn{2}{|c|}{ 統制・標準小作料 } & $5 \sim 8$ & $16 \sim 18$ & $18 \sim 22$ \\
\hline \multicolumn{2}{|c|}{ 水稲作目的のヤミ } & 3 俵 (51) & 2 俵 (34) & 1.5 俵 (25) \\
\hline 小 & 作 料 & & & \\
\hline
\end{tabular}

注 $(1)$ 単位: 千円, 現物は米 $30 \mathrm{~kg}=8,453$ 円として換算.

（2）※は耕作者に加算金は交付されているが，小作料の内 訳に入らない場合であり，※※は耕作者に加算金が交付 されない場合を示す. 
れていた. このらち前者の 3 地区について計画転作に お汀る小作料の決定方法とその他の小作料相場を示し たものが表 3 である.

後野と柏原では転作奖励金の全額と転作実施者に交 付された互助金あるいは自己負担金との合計額が小作 料の算定基礎となっている ${ }^{6)}$. 他方織田では転作奨励 金のらち特定作物加算金と計画加算金を控除した額と 互助金が小作料の算定基礎となっている. 3 地区とも 10 a 当り小作料は 65 千円 70 千円と高水準にあり, 各 地区に持敄る水稲作のヤミ小作料と比較しても高い状 態にある．また水稲作のヤミ小作についてみて子統制 小作料や標準小作料をはるかに上迴っており，計画転 作の小作料がいか沉高水準であるか判断できる.

ところで計画転作に扮活る小作料の高額性について は転作奖励金や互助金の存在が大きく影響している. それは一方でｉ）貸付農家が水稲作の耕作意欲二能力 を保持している. ii ) 契約期間が 1 年と極めて短いこ とから貸付農家は農地貸付けによって生じた余剩労力 を兼業または農業経営に振り向け所得增加をはかるこ とが困難である.などから貸付農家の要求小作料が高 い.これに対してiii）転作作物の裁培経験が少ないこ とから借入農家の危険負担が大きい，iv）転作作物の 収益性は一般に水稲作のそれに比較して低い。などの 理由から借入農家の転作部門収益からの小作料支払能 力は低い.したがって奖励金等を除外した場合の借入 農家の小作料支払能力は貸付農家の要求小作料より低 いのが一般的であり，この場合転作奖励金等が借入農 家の支払可能小作料を補填する役割を果している.

\section{4. 計画転作における小作料の経済的形成要 因}

\section{(1) 計画転作における小作料の形成要因}

計画転作の場合, 公的機関の決定する小作料水準は 転作奖励金の影響を受けて高額であるとはいえ，その 決定要因には経営経済的論理が貫徹しているはずであ る.ここでの課題はこの経営経済的要因について分析 することである．計画転作に和ける小作料の形成要因 を解明する場合, 転作といら経営行動がひとつの鍵と なる。すなわち貸付農家も借入農家も転作以前に獲得 していた何らかの水㸺部門収益を基準に農地貸付けや 借地による転作などの意思決定を行うものと判断でき る. 公的機関の決定する計画転作に括ける小作料の経 営経済的形成要因としては次の諸条件が考兄られる.

i ）転作実施者（借入農家）に関する条件
第 1 の条件は平均的な借入農家の支払可能小作料よ りも基準小作料が低い水準にあることである.この場 合支払可能小作料の中には転作奖励金や互助金の収入 も考虑されなけれぱならない。

第 2 は私経済的所得目標関する条件である．転作 物経営を行う場合その代替部門所得である水稲部門所 得が意思決定の基準となる。すなわち転作部門所得に 奖励金等の収入を加兄た金額が水稲部門所得よりも大 きい場合に農業者は転作を実施する，借地により転作 を行う場合は転作部門所得十奨励金等収入一小作料が 水稲部門所得と等しいかそれ以上でなければ転作物経

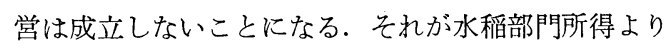
も低い水準であれば，借地によって転作を行らよりも 水稲経営を継続した方が私経済的には合理的である. この条件は収益面で水稲作よりも不利な粗放的穀作に 転作する場合に問題となる。また計画転作のために創 設された互助金制度は奖励金等収入を上積みし，本来 水稲部門所得より不利な転作部門所得を補填する役割 を果たしている.

ii ）貸付農家に関する条件

貸付農家の要求小作料を上廻る水準基準小作料が 決定されていることである.

\section{(2) 小作料の経済的形成要因に関する実証分析}

借入農家の支払可能小作料や貸付農家の要求小作料 の分析は農業経営を土地利用経営体と仮定して行ら純 収益計算であり, 土地純収益は土地への機能的分配概 念である. 他方私経済的目標である農業所得は人的分 配概念である.

ところで土地純収益にしても農業所得にしても経営 面積規模で階層間の較差が执大している点が近年 の特徵である. 借入農家二大規模農家, 貸付農家二零 細規模農家と明確に区分できる近年では収益性に挏け る階層間較差を前提に実証分析する必要がある。計画 転作に括ける農地貢貸借について子例外ではない（表 1)．表 4 は調查地区に㨟ける生産部門収益性を示し ている.

i ）借入農家の支払可能小作料

転作作物の作付けは通常数 $10 \mathrm{a}$ の零細規模で行われ ている．また転作部門は農業経営に新規導入される場 合が多いことから，借入農家の支払可能小作料を考察 する場合の転作部門に打ける土地純収益増加額は平均 土地純収益となる．表 5 では表 4 を基礎湴作奖励金 等の収入をも含めた借入農家の支払可能小作料を示し ている. 
表 4 調查地区に抢ける生産部門別収益性（昭和53年度, $10 \mathrm{a}$ 当り）

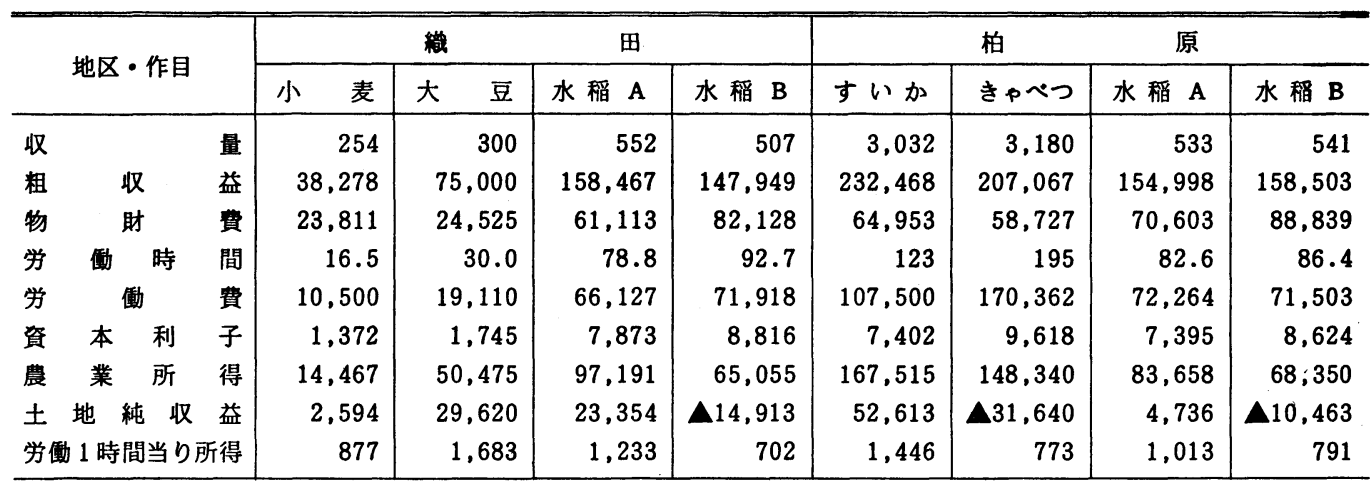

注（1）水稲は農林水産省米生産費調査, 小麦は農協直営の実績, 大豆は普及所の設定モデル係数から加工計算した. すいか, きゃべ つについては先進的農家 $5 \sim 3$ 戸の聞きとり調査の平均值を示した。

（2）水稲 $\mathrm{A}$ は各県平均值，水稲 $\mathrm{B}$ は各県の30 $50 \mathrm{a}$ 規模に関する米生産費である.

(3) 単位 : $\mathrm{kg}$, 円, 時間.

織田, 柏原両地区とも転作奖励金等収入を含めた支 払可能小作料は公的機関の基準小作料を上廻る水準と なっている. しかし転作奖励金等収入を加味しなかっ た場合，転作部門の土地純収益だけでは基準小作料の 支払能力はまったく無いといってよい.

ii ）借入農家の転作部門所得

借地によって転作部門が導入されるための条件式, 転作部門所得十奨励金等収入一水稲部門所得 $\geqq$ 基準小 作料について表 4 および表 5 の資料を基礎に検討す る. 転作部門所得は当然表作（大豆，すいか）と裏作 (小麦，きゃべつ）による所得の合計額である.

（織田地区），大豆十小麦

65 千円 +100 千円 -97 千円 $=68$ 千円 967 千円

（柏原地区），すいか十きゃべつ

316 千円 +55 千円 -84 千円 $=287$ 千円 $>65$ 千円

借入農家の転作部門所得に関する条件では，柏原地 区については労働集約的野菜作の導入により土地面積 当り農業所得の大幅な増加が達成されている.ここで は転作部門所得だけで公的機関の基準小作料を控除し

\section{表 5 支払可能小作料と要求小作料との比較}

\begin{tabular}{|c|c|c|c|}
\hline \multicolumn{2}{|c|}{ 地 } & 絿 田 & 柏 原 \\
\hline \multirow{5}{*}{$\begin{array}{l}\text { 借 支 } \\
\text { 入菢 } \\
\text { 農 能 } \\
\text { 家 作 } \\
\text { の 料 }\end{array}$} & 表作土地純収益 & 29,620 & 52,613 \\
\hline & 表作土地純収益 & 2,594 & $\Delta 31,640$ \\
\hline & 転作梁励金 & 70,000 & 55,000 \\
\hline & 互 助 金 他 & 30,000 & - \\
\hline & 計 & 132,214 & 75,973 \\
\hline \multicolumn{2}{|c|}{ 貸付農家の要求小作料 } & 59,116 & 62,586 \\
\hline
\end{tabular}

（注）単位：円 $/ 10 \mathrm{a}$
ても水稲部門所得を上廻る金額となる．他方織田地区 については労働粗放的小麦・大豆作の導入により転作 部門所得は水稲部門所得よりも减少した結果, 転作部 門所得十奖励金等収入から水稲部門所得を控除した残 額はほぼ公的機関の基準小作料に近似した水準にあ る.すなわち織田地区については農地賃貸借により計 画転作が成立するために農協が転作部門所得＋奖励金 等収入一水稲部門所得に見合う水準で基準小作料を決 定したと判断することも可能である. この限りでは 67 千円の小作料は織田地区に扣いて中核農家が借地によ り計画転作に参加するための最大限の基準である.

粗放的穀作を計画転作の対象作物とした地区に拈い ては転作奖励金十互助金の上限をどの水準に決定する かが公的機関の課題となるところであるが，計画転作 が開始されたばかりの現状では転作実施者(借入農家) に代替部門所得である水稲部門所得が補償される水準 が上限となって，転作奖励金に上積みされる互助金の 水準が決定されているものと判断できよう.

iii）貸付農家の要求小作料

貸付農家の要求小作料は土地貸付けによって減少し た水稲部門の土地純収益額である。しかし現実には計 画転作に打ける農地賃貸借の場合は契約期間が 1 年と 短いことから家族労働の限界機会報酬による評価額は ゼロとなり, 要求小作料は水稲部門所得減少額と近似 した水準となる。

ところで計画転作に打ける農地賃貸借の場合，貸付 農家は経営規模の零細な II 兼農家である. ブロックロ ーテーション方式の場合貸付農家は全階層にわたる が，このうち大規模農家は転作実施者として計画転作 
に参加しており，純粋の土地用役供給者として機能し ている農家は自家飯米確保を目的として水稲作を継続 してきた零細農家と考兄られる。旮れゆ貸付農家の 要求小作料を計算するための資料には50 a 未満農家 （20 50 a 規模層）の水稲部門所得一物財資本利子を 利用する.こうして両地区の要求小作料を計算した結 果は次のようになる。

（織田地区）59千円 -3 千円 $=56$ 千円 $<67$ 千円 （柏原地区） 63 千円 $\fallingdotseq 65$ 千円

織田地区に括ける 3 千円の控除額は計画転作に伴う 互助金制度の資金として水稲作農家に賦課される $10 \mathrm{a}$ 当り金額である. 両地区とも貸付農家の要求小作料は 公的機関の基準小作料に近似した水準となっている. これは結局零細な貸付農家においても水稻作であれば 充分耕作可能であるにもかかわらず行政の強制力をも って転作作物の誘導を図ろらとした結果，貸付農家に は既得権である水稲部門所得を補償するといら意味で 小作料近似した基準小作料が決定されたものと考兄 られょう。

\section{5.むすび}

昭和53年度から始まった計画転作の中には集団的土 地利用と呼称できるいくつかの事例が成立している. その場合の農地賃貸借に括ける小作料は従来集団的田 畑輪換の一部においてみられたものと同様に高い水準 にある. 高額小作料を形成させてきた集団的田畑輪換 の場合は高収益作物を対象とし, それゆ兄に要求小作 料を大幅に超過する支払可能小作料が要求小作料を基 準に形成された実勢小作料の支払能力の基礎となって いた．これに対して計画転作の場合は貸付農家の水稲 部門所得に近似した要求小作料に規定されて基準小作 料二実勢小作料が形成されている．この場合転作部門 収益からみた支払可能小作料は実勢小作料を大幅に下 趣って扣り，転作奖励金や互助金が存在しなかった場 合は農地賃貸借が成立不可能な状態にある。 その限り では転作奖励金や互助金制度は借入農家の支払可能小 作料を大幅に補填する役割を果している.

ところで転作奖励金や互助金が交付される経済的根 拠は転作実施者の行動原理に求められる。計画転作の 少からぬ事例で採用されている互助金制度は転作実施 者 (借入農家) の収益である転作部門所得十奖励金等 収入一基準小作料が代替部門所得である水稲部門所得 に匹敵するよう設けられた施策であると判断できる。 それゆ克転作奖励金十互助金の水準は地区内の水稲部
門所得, 転作部門所得, 基準小作料を变数として決定 されるものと考兄られる.

また計画転作には自然発生的な集団的田畑輪換や従 来の土地利用権仲介制度には見られなかった特徵があ る.すなわち土地利用権の移動を管理・調整する公的 機関の強い規制力と中核農家を中心に組織された機能 的生産組織の存在である。たしかに計画転作は国から の奖励補助金を伴った行政主導型の集団的土地利用で はあるが, 地元農民, 農協, 普及所等の英知と努力の 結果農業生産の組織化・計画化といら点では従来の経 験にはみられなかった特徵をもっている.

注 1) (1)梶井功著『農地法的土地所有の崩壊』, 昭 和 52 年 10 月

(2) 梶井功著『土地政策と農業』, 昭和 54 年. 3 月 参照.

2) 以上 $\ulcorner 」$ 内次の文献からの引用である.

(3)伊藤喜雄著『現代借地制農業の形成』, 1979 年11月，P154.

3) 水田利用再編下で生じてきているこのような農 地の利用関係を传貸借, 使朋貸借, 請負耕作 (単 なる代理転作）のいずれとみなすかについては刘 象事例の差異などから論が分れるとてろである。 本稿で検討対象とした調查地区の事例については 次の理由からこれを賃貸借とみている。第 1 亿調 查地区の場合，土地利用に伴なう当事者間の権利 や義務の帰属, 損益负担の帰属加ら考えて, 耕作 事業の主体は転作実施者であると認められうる。 それゆえ耕作事業主体が転作以前の土地所有者か ら転作実施者传変更されているととから，てのよ うな農地利用関係は請負耕作というよりは農地賃 貸借と判断すべきである。第 2 にてれらの調査地 区では転作奖励金, 互助金が寒質的任転作実施者 に交付されており，転作実施者から土地所有者に 支払われる土地用役の対価は小作料であると認め

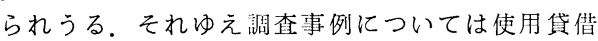
というよりは賃貸借は判断すべきである.

4) 小池氏は計画転作を団地形成の方法の違いから i）利用権調整型，ii）一部農家集中型，iii）任 意参加型の 3 つに区分している。 また島氏は集団 組織の差異加ら i）全戸参加・共同管理型， ii） 全戸参加・個別管理型，iii）集时請負・共同管理 型，iv）集団請負 - 個別管理型, v ) 自作地請负 型の 5 つに区分している。農地賃貸借とは無関係 に成立しえる計画転作には小池氏のiii）または島 氏のv）が該当するすのと思われる。

(4) 小池恒男稿「計画転作」と集落農業の再編」, 『侲林業間题研究』14の4 所收, 1978年12月.

(5)荀均稿「集団転作組織 づくりと普及活動」, 『技術之普及。昭和 54 年 8 月号所收。

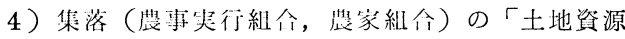
管理機能」については次の文献を参照されたい。 
（6) 福田稔稿「集落の資源管理機能とその限界」, 『農村地域の再編と管理に関する研究』所収, 昭和 54 年 5 月.

(7) 高山敏弘稿「集落の変容と集落機能」, 『集落 機能と新農政の展開』所収, 昭和 54 年 3 月。

(8) 長憲次稿「農業経営の展開と村落」, 農業経 営構造問題研究会編『農業経営の歴史的課題』 所収, 昭和 53 年 12 月。

本稿では集落の自治組織の諸機能について直 接検討しているわけではない，その中でも「土 地資源管理機能」に関連して，前述した土地利 用権の移動に伴う農事実行組合等の 3 つの管理 ・調整機能に限定して述べているわけである。

5) 調查地区のうち転作実施者に互助金を交付して いる地区は後野と織田であり，柏原では転作実施 者に直接交付する互助金制度は存在せず, 計画転
作の小作料と転作奖励金との差額10干円は転作実 施者（借入農家）が個人負担している。また後野 と織田における互助金制度むその資金調達方法に おいて差異が見られる. 後野地区では互助金の資 金を拠出するため地区内全農家を対象にi）農協 を通じて売渡した米 1 袋（30kg）につき 120 円， ii）水稲作付面積 10 a につき 340 円の賦課金を徵収 し, 転作実施者に 10 a 当り 15 千円の互助金を交付 している。乙の事業の推進主体は加悦町である. 織田地区では互助金の資金を拠出するため計画転 作に参加していない農家を対象に経営面積 10 a つき 3 千円の賦課金を徵収し，転作実施者に10 a 当り 30 千円の互助金を交付している。乙の事業の 推進主体は織田農協が担当している。

（筆者・京都大学農学部） 